\title{
Rhynchophorus palmarum used in Traditional Medicine in the Peruvian Amazon
}

\author{
Cesar Delgado $^{1^{*}}$, Rosa Romero ${ }^{2}$, Rosa Vásquez Espinoza ${ }^{3}$, Marcial Trigozo $^{1}$, and Rocio Correa ${ }^{1}$ \\ ${ }^{1}$ Programa de Investigación en Biodiversidad, Instituto de Investigaciones de la Amazonía Peruana, Iquitos, Perú. \\ ${ }^{2}$ Departamento de Lenguas Nativas y Extranjeras, Universidad Nacional de la Amazonía Peruana, Iquitos, Perú. ${ }^{3}$ Program of \\ Chemical Biology, University of Michigan, Ann Arbor, USA. \\ *cdelgado@iiap.gob.pe
}

\begin{abstract}
Ethnoentomological research focuses on the wealth of knowledge about insects used by indigenous communities. Here, we examine the medicinal use of insects, with a particular focus on Rhynchophorus palmarum, also known as suri, by indigenous peoples in the Peruvian Amazon. Between January 2014 and November 2015, a semistructured survey was conducted in six communities belonging to Kukama-kukamiria, Tikuna, and Awajum ethnic groups. Each participant answered three key questions: i) what insects do you use to treat your diseases; ii) what diseases do you treat; and iii) how do you treat each disease? A total of 63 people were interviewed. Over half of the interviewees from the three ethnic groups mentioned using the larva of the $R$. palmarum for medicinal purposes. The oil of the larva is used to treat more than ten diseases, particularly respiratory illnesses. Chemical analysis of the larvae indicates the presence of linoleic and linolenic acids, which confer antimicrobial and anti-inflammatory properties.
\end{abstract}

Received February 22, 2018

OPEN ठACCESS

Accepted October 30, 2019

DOI 10.14237/ebl.10.1.2019.1271

Published December 10, 2019

Keywords Insects, Beetle, Larvae, Ethnomedicine, Peru

Copyright (c) 2019 by the author(s); licensee Society of Ethnobiology. This is an open-access article distributed under the terms of the Creative Commons Attribution-NonCommercial 4.0 International Public License (https://creativecommons.org/licenses/by-nc/4.0), which permits non-commercial use, distribution, and reproduction in any medium, provided the original author and source are credited.

\section{Introduction}

A multitude of cultures around the world use insects and the substances extracted from them as therapeutic resources to treat an array of lifethreatening conditions (Costa Neto 2005). Mesopotamian cuneiform writings and texts from approximately 5,000 years ago indicate the use of fireflies, mantis, and other unidentified insects to treat diseases (Lupoli 2010; Mazars et al. 2004). Some cultures in China also started using insects in folk healing many years ago. Some Chinese people continue to use over 300 species of insects from 14 orders, 63 families and 70 genuses in their traditional medicine practices, thus employing the greatest reported diversity of medicinal insects worldwide (Feng et al. 2009; Lupoli 2010). Other parts of the world, including South America, also use insects as healing agents. For example, in Brazil, up to 82 types of insects are known to be used for medical purposes (Costa Neto et al. 2006).
Medicinal insects are typically consumed alive, cooked, ground, or used in infusions, ointments, and plasters. They are used in both preventive and curative medicines, as well as in magical religious rituals that claim to promote health, physical, and mental well-being (Clausen 1954; Costa Neto 2002, 2005). Previous reports have shown that the chemical and biochemical components of various insects and their derivatives contribute to their immunological, analgesic, anti-inflammatory, antibacterial, diuretic, anesthetic, and antirheumatic properties (Cherniack 2010; Costa Neto 2002, 2005; Lupoli 2010).

Larva of the Rhynchophorus palmarum is traditionally used as both food and medicine in tropical areas of the Western Hemisphere, including the Amazon Rainforest (DeFoliart 1993). Several studies indicate that many ethnic groups and indigenous peoples from the continental Amazon, including countries such as Venezuela, Peru, Paraguay, Ecuador, Colombia, and Brazil, use larva of the R. palmarum on a regular basis 


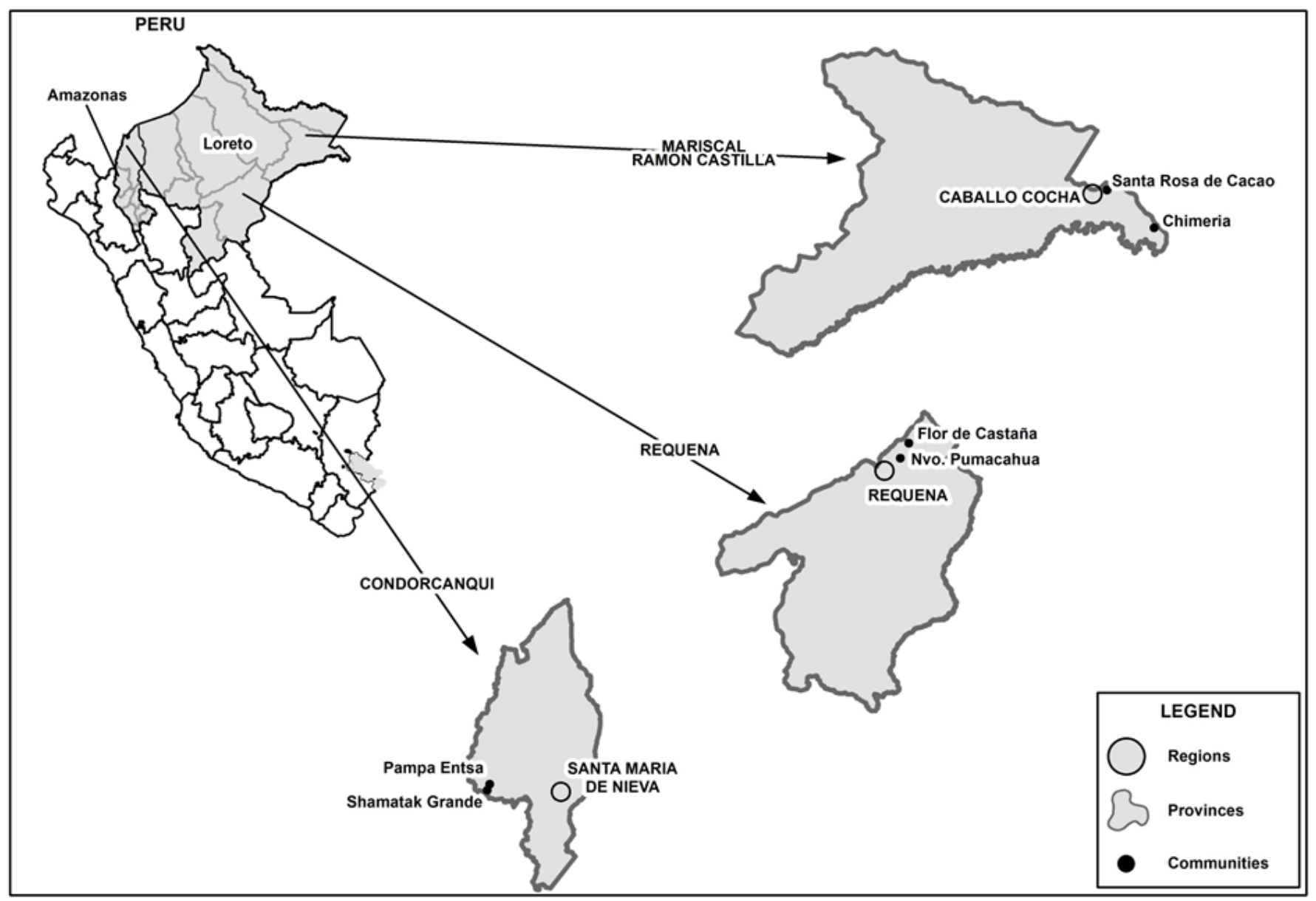

Figure 1 Map of the study areas. Figure by Cesar Delgado.

- making it the most widely used medicinal insect in the Amazon Rainforest (Cartay 2018; Casas et al. 2018; Cerda et al. 2001; Costa Neto and Ramos 2006; Delgado et al. 2007, 2008; Dufour 1987; Manno et al. 2018; Onore 2005; Paoletti et al. 2000; Sancho et al. 2015; Santos 2011; Vera and Brand 2012). Unfortunately, only a limited number of scientific studies document the Amazonian larva of the $R$. palmarum's modes of use and healing properties. Some of these investigations describe Bolivian communities using the insect to treat respiratory illnesses (Bourdy et al. 2000); Peruvian indigenous groups consuming it to treat rheumatism, pulsaria, and respiratory diseases (Delgado 2008); and Brazilian indigenous peoples using the larva to reduce fever and treat headaches and boils (Almeida 2005; Alves and Alves 2011; Alves and Días 2010). The objectives of our research were to: 1) document modes of use for larva of the $R$. palmarum in three Peruvian Amazonian indigenous groups' traditional medicine practices, and 2) summarize current knowledge about the larva's chemical and biochemical composition. This report expands the scientific literature on Amazonian medicinal insects and their use in folk medicine, while serving as a narrative review regarding the chemical level investigation of larva from the R. palmarum to understand its medicinal value.

\section{Methods}

The study was conducted from January 2014 to November 2015 in six communities belonging to three ethnic groups, including the Kukama-Kukamiria community of Nuevo Pumacahua (-4.9226, -73.6827) and Flor de Castaña (-4.7701, -73.5978), Requena Province, Loreto Region; the Tikuna community of Chimeria (-4.1684, -70.0432), and Santa Rosa de Cacao (-3.8999, -70.4759), Mariscal Ramón Castilla Province, Loreto Region; and the Awajum community of Pampa Entsa (-4.5293, -78.4620) and Shamatak Grande (-4.5802, -78.4805) Condorcanqui Province, Amazonas Region (Figure 1). From a linguistic 

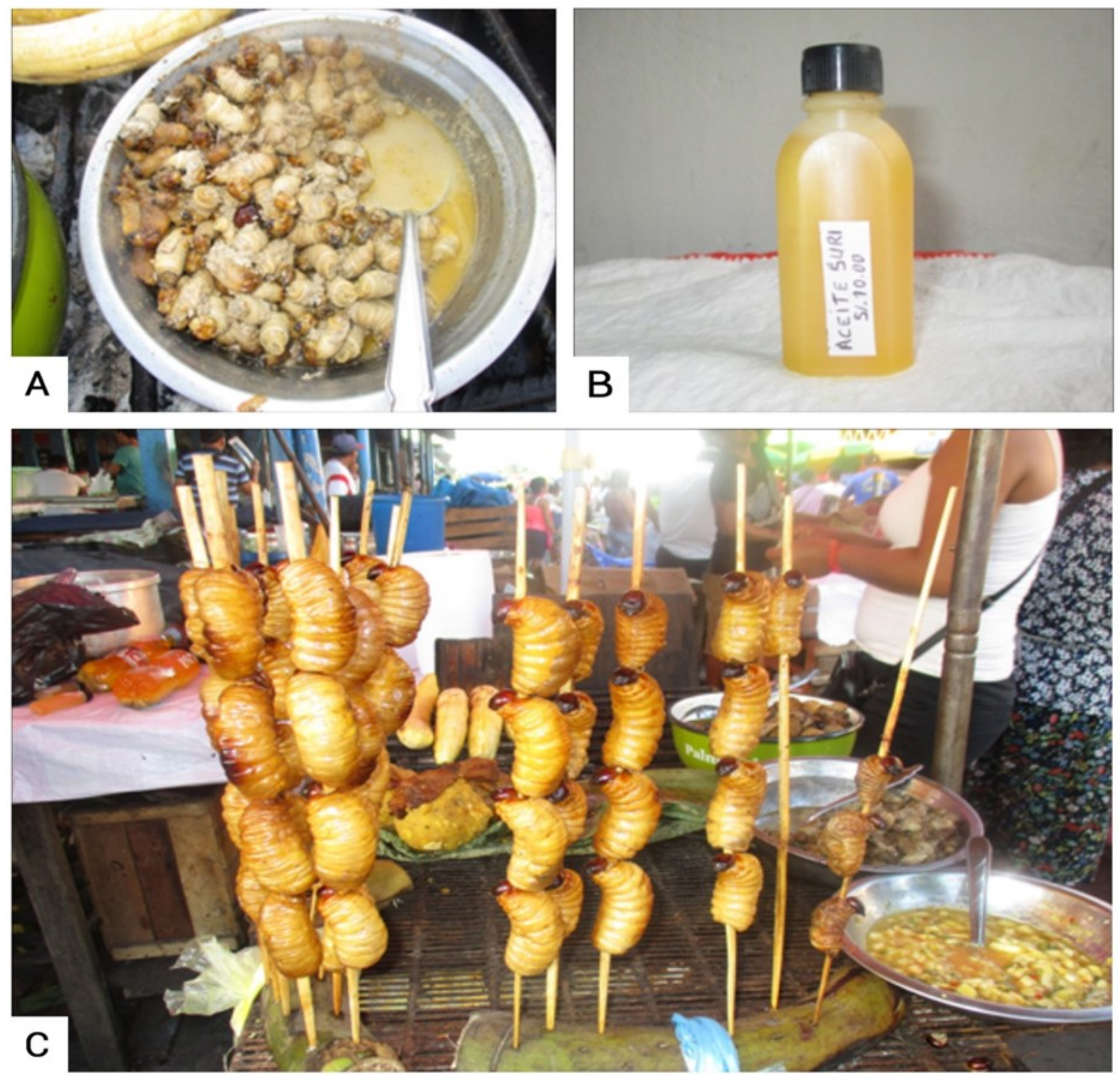

Figure 2 Commercialization of suri in local markets surrounding the indigenous communities surveyed. A Extraction of the suri oil in the Nanay market located in the Kukama-Kukamiria community; B Suri oil in a plastic bottle ready for commercialization in the Nanay market. A $40 \mathrm{~mL}$ bottle costs USD 3.09; C Roasted suri ready for consumption with tacacho or bananas. Photo by Cesar Delgado.

perspective, the Kukama-Kukamiria belong to the Tupí-Guaraní family and the Awajúm to the Jíbaro family, while the Tikuna are considered an independent group belonging to the Tikuna family (MINEDU 2013). Currently, most members of these communities are bilingual - they speak Spanish and their native languages. These communities are all characterized by the presence of a subsistence economy, relying on horticulture, fishing, hunting, and gathering vegetables and fruits to feed themselves and their families. Some of them also raise chickens, pigs, and cattle. 
Semi-structured surveys were designed for interviews with people over the age of 50, and were mostly carried out in Spanish. Whenever necessary, a bilingual local school teacher or community leader translated the questions into the native language of the community. Each interviewee was shown 24 x 17 $\mathrm{cm}$ photographic sheets that portrayed the adult and larval stage of $R$. palmarum to ensure the right species was recognized and identified. The survey included three specific questions: 1) what insects do you use to treat diseases, 2) what diseases do you treat, and 3) how do you treat each disease? These open-ended questions were designed to facilitate dialogue with the interviewee, and allow interviewers to gain a unique perspective into individuals' traditional use of insects as medicines.

\section{Results and Discussion}

Suri in Nutrition and Food

Larva of the R. palmarum, traditionally known as suri, live in the stipe of native and non-native Amazonian palm trees species and feed on decaying organic materials. In order to obtain suri, the indigenous people first cut palm trees down and make lateral cuts in the trunks where they deposit masato (fermented yucca mass Manihot esculenta) or urine (Delgado et al. 2008). This practice aims to increase the production of larvae in each tree by attracting the largest possible number of adult insects to the trunk to encourage mating and, consequently, increase the number of eggs laid. Larvae harvesting takes place approximately two to four months after cutting the tree down (Cartay 2018; Delgado et al. 2008). Exact timing varies according to the tree species and season. During the larva farming period, community members periodically monitor the larva population's development by listening for the humming noise produced by individual larvae. They also protect the trunk from external factors like the sun. If the trunk is exposed to intense insolation, the organic materials that larvae feed on become dehydrated, and, eventually, the larvae will die.

Although suri grows in thirty-one vegetable species (Sanchez et al. 1993), the indigenous people prefer to collect larvae from the native palm tree Mauritia flexuosa (Delgado et al. 2008), because they claim the larvae grow better, provide more protein, and have improved healing properties. Cerda et al. (2001) reported that the R. palmarum larvae raised in M. flexuosa have greater protein content and higher calcium, phosphorus, magnesium, and potassium levels as compared to R. palmarum larvae growing in other palm trees. In a ten meter-long $M$. flexuosa trunk, indigenous peoples collect approximately 224 larvae and 12.1 grams of protein per larva. Thus, each of these trunks produces close to three kilograms of protein. Cartay (2018) performed studies with the Peruvian Amazonian Bora and Yagua indigenous communities and determined that they could produce approximately 500 larvae per trunk. This suggests that suri contributes six kilograms of protein per trunk in these communities.

However, R. palmarum is not eaten by all indigenous groups in the Amazon Rainforest (Paolleti et al. 2000). In some communities, suri is used as a food source only during the wet season when fishing and hunting are affected by the heavy rains (Cartay 2018).

Indigenous people typically prefer to eat the $R$. palmarum larvae over the adult insect. When consuming the adult insect, they remove the wings, head, and legs. Unlike the adult, the larvae are eaten whole, either raw, grilled, boiled, or in patarashca (larvae packed in banana or "bijao" (Calathea lutea) leaves). Sides may include yucca, banana, or native potatoes. Other individuals use the suri as an ingredient to season their food. Currently, suri is sold in local markets and tourist restaurants in the Peruvian Amazon's large cities, including Iquitos and Pucallpa

Table 1 Comparison of the fatty acid composition (\%) of the digestive fat content (CGD) of the R. palmarum larva represented as a percentage.

\begin{tabular}{llll}
\hline Fatty Acid & Dué el al. 2009 & Vargas et al. 2013 & Sancho et al. 2015 \\
\hline Myristic (C14:0) & 2.54 & 2.27 & 2.80 \\
Palmitic (C16:0) & 40.44 & 43.65 & 28.00 \\
Palmitoleic (C16:1) & Not reported & 1.01 & 1.20 \\
Stearic (C18:0) & 1.99 & 8.52 & 5.90 \\
Oleic (C18:1) & 46.71 & 41.57 & 59.20 \\
Linoleic (C18:2) & 6.24 & 1.93 & 1.10 \\
Linolenic (C18:2) & Not reported & 1.05 & 0.30 \\
\hline
\end{tabular}




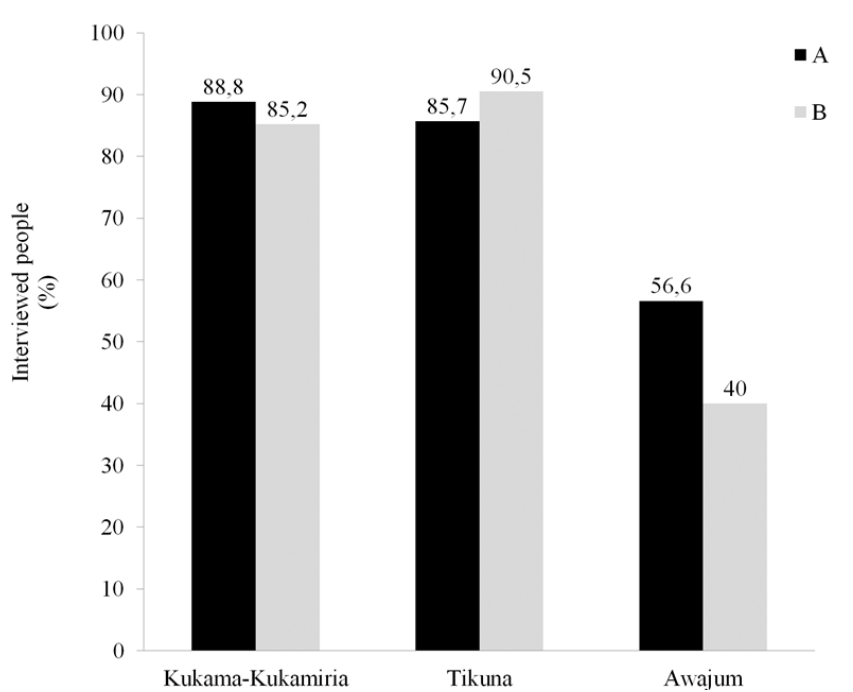

Figure 3 Use of suri in traditional medicine in three ethnic groups of the Peruvian Amazon. A Percentage of people who use suri to treat different diseases; B Percentage of people who use suri oil to treat respiratory diseases. Figure by Cesar Delgado.

(Cartay 2018; Delgado et al. 2008). When sold in markets, suri is often served fried or grilled on wooden sticks and comes with yucca, banana, tacacho, farina, or macambo toasted seeds (Theoborma bicolor) (Figure 2c).

Due to its high levels of protein, fat, and calories, suri is an important component of the local diet. Protein content varies from nine to 13 grams per 100 grams of fresh weight. Fat varies between 22 to 38 grams per 100 grams. The caloric content in suri is between 188 to 310 calories per 100 grams (Delgado et al. 2008; Vargas et al. 2013). In other areas of the Amazon, studies report protein content reaching up to 25 grams per 100 grams of dry weight (Cerda et al. 2001; Doufor 1987).

Seven fatty acids, including linoleic and linolenic acids, have been found in suri (Dué et al. 2009; Sancho et al. 2015; Vargas et al. 2013; Table 1). Moreover, 19 amino acids and nine essential amino acids, including lysine, isoleucine, leucine, valine, threonine, and phenylalanine have been identified in the larva (Cerda et al. 2001; Manno et al. 2018; Vargas et al. 2013). Additionally, R. palmarum contains vitamins and minerals, including vitamin $A$ in the form of retinol and vitamin E. Retinol and vitamin $\mathrm{E}$ levels can reach up to 85 micrograms and 44 micrograms per 100 grams of dry weight respectively. Minerals found in suri include calcium, potassium, phosphorus, sodium, and iron (Cerda et al. 2001).
Using these values, and considering standard nutrition requirements, a child between seven and 11 years old would need to consume 20 suri larvae a day in order to meet the recommended levels of daily protein intake and $23 \%$ of the suggested levels of retinol. Eating five larvae would satisfy the recommended daily levels of vitamin $\mathrm{E}$ intake.

Suri in Medicine

Interview answers were collected from 63 people (78\% male and 22\% female): 27 responses were from the Kukama-Kukamiria communities (81\% male and 19\% female), 21 responses were from the Tikuna communities (85\% male and 15\% female), and 15 responses from the Awajun community $(60 \%$ male and $40 \%$ female). The first question on the survey ask about insects used to treat diseases, to which respondents mentioned 29 insects used in traditional medicine-many of them used alone, and others used in combination with vegetable structures from different species (leaf, bark, and root). Individuals from the three different indigenous groups mentioned suri among their first responses (Figure 3). Notably, there was homogeneity in the use of the specimen ( $p$ $<$ 0.001; Chi-square test). However, various Peruvian Amazon communities call suri by different names. For example, in the Kukama-Kukamiria dialect, suri is known as miriti-ura; in Tikuna and Awajum-bukin, it is called boxõ.

The majority of interviewees acknowledged using suri primarily to cure, treat, and prevent diseases. Therefore, the second survey question ("What diseases do you treat?") was modified to focus on the use of suri and read "What diseases do you treat with sur?". The Kukama-Kukamiria and the Tikunas use suri mainly to treat diseases associated with the respiratory system (flu, colds, coughs, and asthma), while the Awajum use suri to treat scurvy (Figure 3). However, we found homogeneity in the use of suri to treat respiratory disease in all three ethnic groups $(\mathrm{p}<$ 0.001; Chi-square test). In addition, some interviewees from the three indigenous groups reported using suri to cure rheumatism, dislocations (crippled), whooping cough (also known as pertussis), and tuberculosis. Members of the Tikuna and Kukama-Kukamiria communities also mentioned using suri to heal pulsaria.

More than $90 \%$ of interviewees mentioned ingesting live suri or using it as an oil to treat the diseases mentioned above. To extract suri oil, indigenous peoples place the larva in a pot or frying pan over a fire until the larva is completely melted and 
only the cuticle remains (Figure 2a). Older people in the communities extract the oil by exposing the suri to the sun on a metal plate (can or calamine).

As we have shown, some indigenous communities in the Amazonian countries use $R$. palmarum larvae for traditional medicine practices (Almeida 2005; Alves and Días 2010; Alves and Alves 2011; Bourdy et al. 2000; Delgado et al. 2008). Suri's high usage in sparked its entry into the market economy. Local markets surrounding the communities are now commercializing suri, albeit in an informal manner (Figure 2b,c).

\section{Suri and Essential Fatty Acids}

Studies on the chemical composition of R. palmarum oils reported the identification of up to eight saturated and unsaturated fatty acids, supporting the high nutritional value of this species. These studies were conducted in different jungle areas worldwide, including Côte d'Ivoire (Dué et al. 2009; Gbogouri et al. 2013), the Peruvian Amazon (Vargas et al. 2013), and the Ecuadorian Amazon (Sancho et al. 2015; Table 1). Suri oil contains high levels of palmitic and oleic acid, as well as moderate levels of linoleic and linoleic acids. Thus, it is possible to imagine that the fatty acid chemical composition present in the suri oil contributes to its nutritional and medicinal value and thus, helps explain why the inhabitants of the communities surveyed report the efficacy of using suri to treat illnesses.

The most important essential fatty acids for human health are linoleic acid ( $\omega$-six series) and $\mathrm{a}$ linolenic acid ( $\omega$-three series). Linoleic acid is a polyunsaturated fatty acid utilized in the biosynthesis of arachidonic acid. This acid is enzymatically derived into some prostaglandins - active lipid compounds involved in inflammation (Dewich 2009). Similar to linoleic acid, a-linolenic acid is an essential fatty acid because the human body is not capable of synthesizing it from food. Thus, humans must acquire it through diet for proper health. Through a series of desaturation and elongation reactions, a-linolenic acid derives into docosahexaenoic acid and eicosapentaenoic acid, two important acids in the regulation of inflammatory conditions. Thus, linoleic and alinolenic acids play an important role in cytoprotection and anti-inflammation of the human body (Pinazo-Duran and Boscá-Gomar 2012; Valenzuela et al. 2011). Some studies have shown that the consumption of these two essential fatty acids may be effective in the treatment and prevention of various diseases including cardiovascular diseases, neurodegenerative diseases, inflammation, cancers, rheumatoid arthritis, and ischemia or reperfusion injury (Valenzuela et al. 2011).

Futhermore, palmitic acid is the most common saturated fatty acid in animals (Waite et al. 1962) and plays a key role in various fundamental biological functions. It is also an important component of human breast milk, and previous studies have suggested it is critical for proper infant health (Innis 2016). Additionally, animal studies have shown that this saturated fatty acid has mild antiatherosclerotic and antioxidant properties (Elagbar et al. 2016). Another important fat in human diet is oleic acid, a monounsaturated $\omega$-nine fatty acid. Previous studies suggest that the consumption of oleic acid may slow the progression of the fatal condition adrenoleukodystrophy and may reduce the risk of coronary heart disease (Lopes et al. 2010).

\section{Most Common Diseases: Symptomatology and Treatment}

Respiratory diseases were treated by ingesting suri oil (in volume equivalent to three larvae) three times a day for five to seven days. Some acknowledged continuing the treatment until the illness was completely eradicated. In addition, they mentioned rubbing the oil in their hands until warm and then rubbing the oil over the chest of the patient. They explained that an increase in temperature when rubbing the oil led to better penetration of it into the affected body part. Finally, to treat tuberculosis, interviewees recommended continuing the treatment for a minimum of six months.

In the Awajum community, scurvy is frequently detected in children one to three years old, presenting as ulcerations on the lips and gums and, in some cases, producing small hemorrhages. The treatment consists of removing the skin and head of the suri and using the bait to rub the affected parts (lips and gums) until a blackish coloration forms on the patient's skin. Treatment should be done for a minimum of three days or until the ulcers heal.

Survey respondents mentioned that pulsaria is the result of a disorderly diet and develops because people eat their food at inconsistent times or fast for several hours or days. The disease produces pain and a burning sensation in the mouth of the stomach. Health care professionals working in rural communities, report that patients with these symptoms typically have stomach ulcers. The 
treatment consists of rubbing suri oil over the patient's stomach at night for seven days or more.

Interviewees mentioned that rheumatism is caused by "cold disease." They describe "cold disease" as the most common symptom of rheumatism and mention that "cold disease" occurs because community members remain wet for extended periods of time due to fishing and farming activities, working for multiple hours of in constant rain. The local treatment for rheumatism is to place suri oil in a spoon or a can and heat it to its boiling point. The hot oil is then applied to the affected joint. On the other hand, the treatment for dislocations is to warm up suri oil by rubbing it on the hands and immediately rubbing it over the dislocated area while adding pressure and repeating this process until the dislocated bone goes back into place. Some interviewees reported that the treatment for dislocations may be accompanied by prayers.

\section{Conclusions}

Suri (or R. palmarum) is the insect most widely used by the indigenous groups interviewed for this research. Suri complements the local indigenous diet and provides high levels of protein, vitamins, and essential fatty acids. The species we studied is used to treat more than ten diseases, primarily respiratory diseases, such as cough, asthma, whooping cough, and colds, but also tuberculosis, rheumatism, and scurvy dislocations. The interview results and literature review support the use of suri in traditional medicine and suggest that suri's healing properties, as reported by the indigenous communities, may be explained by the presence of fatty acids in suri, primarily due to the high composition of the precursors of essential fatty acids: linoleic (Series $\omega$-six) and linolenic (Series $\omega$ three) acids.

Over time, suri may play a pivotal role in the economic development of the Peruvian Amazon's ethnic communities due to the rapid increase in suri consumption and commercialization. It is necessary to carry out further chemical and pharmacological studies about suri as well as other insects present in the Amazon Rainforest because given the high biodiversity of their environment, novel natural products may be isolated from these insects. Discovering previously unknown compounds may help expand chemical diversity as well as improve drug development efforts to treat various health conditions.

\section{Acknowledgments}

The study was carried out with funds from the Amazon Biodiversity program of the Instituto de Investigaciones de la Amazonía Peruana (IIAP). We thank all the participants in the study, especially the indigenous communities, Kukama-Kukamiria, Tikuna, and Awajum communities, for their collaboration in the field work. Voucher Specimens were deposited in the Referential Biodiversity Collection of the Instituto de Investigaciones de la Amazonía Peruana.

\section{Declarations}

Permissions: The Amazon Biodiversity Research

Program, part of the Instituto de Investigaciones de la Amazonía Peruana, approved this research within the No31-2014/IIAP and 31-2015/IIAP projects. Permits to access and carry out research in the communities were obtained prior field work. The Peruvian Government's National Forestry and Wildlife Service granted permits to collect biological materials.

Sources of funding: The research was funded by the Instituto de Investigaciones de la Amazonía Peruana (IIAP). Project No 31-2014/IIAP and No 31-2015/ IIAP.

Conflicts of Interest: None declared.

\section{References Cited}

Almeida, A. V. 2005. Prescrições Zooterápicos Indígenas Brasileiras nas Obras de Guilherme Piso (1611-1679). Atualidades em Etnobiologia e Etnoecologia, edited by A. G. C. Alves, R. F. P. Lucena, and U. P. Albuquerque, pp. 47-601. Sociedade Brasileira de Etnobiologia e Etnoecologia Press, Recife, Brasil.

Alves, R. R. N., and T. L. P. Dias. 2010. Usos de Invertebrados na Medicina Popular no Brasil e suas Implicações para Conservação. Tropical Conservation Science 3:159-174.

DOI:10.1177/194008291000300204.

Alves, R. R. N., and H. N. Alves. 2011. The Faunal Drugstore: Animal-Based Remedies Used in Traditional Medicines in Latin America. Journal of Ethnobiology and Ethnomedicine 7:2-43. DOI:10.1186/1746-4269-7-9.

Bourdy, G., S. DeWalt, A. Roca, L. R. Chavez de Michel, E. Deharo, V. Munoz, L. Balderrama, C. Quenevoc, and A. Gimenez. 2000. Medicinal Plants Uses of the Tacana, An Amazonian Bolivian Ethnic Group. Journal of Ethnopharmacology 70:87-109. DOI:10.1016/S0378-8741(99)00158-0. 
Cartay, R. 2018. Between Shock and Disgust: The Consumption of Insects in the Amazon Basing. The Case Of Rhynchophorus Palmarum (Coleoptera: Curculionidae). Revista Colombiana de Antropología 54:143-169. DOI:10.22380/2539472x.465.

Casas, R. R., L. Pawera, P. P. P. Villegas, and Z. Polesny. 2018. Beetles, Ants, Wasps, or Flies? An Ethnobiological Study of Edible Insects among the Awajum Amerindians in Amazonas Peru. Journal of Ethnobiology and Ethnomedicine 4:2-11. DOI:10.1186/ s13002-018-0252-5.

Cerda, H., R. Martínez, N. Briceño, L. Pizzoferrato, P. Manzi, M. T. Ponzetta, O. Marín, and M. G. Paoletti. 2001. Palm Worm: (Rhynchophorus Palmarum) Traditional Food in Amazonas Venezuela-Nutritional Composition, Small Scale Production and Tourist Palatability. Ecology of Food and Nutrition 40:13-32.

DOI:10.1080/03670244.2001.9991635.

Costa Neto, E. M. 2002. The Use of Insects in Folk Medicine in the State of Bahia, Northeastern Brazil, with Notes on Insects Reported Elsewhere in Brazilian Folk Medicine. Human Ecology 30:245-262. DOI:10.1023/A:1015696830997.

Costa Neto, E. M. 2005. Entomotherapy, or the Medicinal Use of the Insects. Journal of Ethnobiology 25:93-114. DOI:10.2993/0278-0771(2005)25 [93:EOTMUO]2.0.CO;2.

Costa Neto, E., and M. J. Ramos-Elorduy. 2006. Los Insectos Comestibles de Brasil: Etnicidad, Diversidad e Importancia en la Alimentación. Boletín Sociedad Entomológica Aragonesa 38:423-442.

Costa Neto, E. M., J. Ramos-Elorduy, and J. M. Pino. 2006. Los Insectos Medicinales de Brasil: Primeros Resultados. Boletin Sociedad Entomológica Aragonesa 38:395-414.

Cherniack, E. P. 2010. Bugs as Drugs, Part 1: Insects. The "New" Alternative Medicine for the 21 st Century. Alternative Medicine Review 15:124-135.

Delgado, C., G. Couturier, and K. Mejia. 2007. Mauritia Flexuosa (Arecaceae: Calamoideae), An Amazonian Palm with Cultivation Purposes in Peru. Fruits 62:157-168. DOI:10.1051/ fruits:2007011.

Delgado, C., G. Couturier, P. Mathews, and K. Mejía. 2008. Producción y Comercialización de Larva de
Rhynchophorus Palmarum (Coleoptera: Dryophtoridae) en la Amazonía Peruana. Boletín Sociedad Entomológica Aragonesa 41:407-412.

Dewich, M. P., ed. 2009. Medicinal Natural Products: $A$ Biosynthetic Approach. 3rd edition. John Wiley, Chichester/West Sussex, United Kingdom.

Dué, E. A., H. C. B. L. Zabri, J. P. E. N. Kouadio, and L. P. Kouamé. 2009. Fatty Acid Composition and Properties of Skin and Digestive Fat Content Oils from Rhynchophorus Palmarum L. Larva. African Journal of Biochemistry Research 3:089-094.

DeFoliart, G. R. 1993. Hypothesizing about Palm Weevil and Palm Rhinoceros Beetles Larvae as Traditional Cuisine, Tropical Waste Recycling, and Pest and Disease Control on Coconut and Other Palms - Can They be Integrated?. Principes 37:4247.

Dufour, D. L. 1987. Insects as Food: A Case Study from the Northwest Amazon. American Anthropologist 89:383-397.

DOI:10.1525/aa.1987.89.2.02a00070.

Elagbar, A. Z., R. R. Naik, K. A. Shakya, and K. S. Bardaweel. 2016. Fatty Acids Analysis, Antioxidant and Biological Activity of Fixed Oil of Annona muricata L. Seeds. Journal of Chemistry 2016:1-6. DOI:10.1155/2016/6948098.

Feng, Y., M. Zhao, Z. He, Z. Chen, and L. Sun. 2009. Research and Utilization of Medicinal Insects in China. Entomological Research 39:313-316. DOI:10.1111/j.1748-5967.2009.00236.x.

Gbogouri, G. A., G. A. M. Beugre, K. Brou, O. A. Atchibri, and M. Linder. 2013. Rhynchophorus Palmarum L. Larva, An Edible Insect in Côte D'Ivoire: Nutritional Value and Characterization of the Lipid Fraction. International Journal of Chemistry Sciences 11:1692-1704.

Innis, S. M. 2016. Palmitic Acid in Early Human Development. Critical Reviens in Food Science and Nutrition 56:1952-1959.

DOI:10.1080/10408398.2015.1018045.

Lopez, S., B. Bermudez, Y. M. Pacheco, A. Ortega, L. M. Varela, R. Abia, and F. J. G. Muriana. 2010. Oleic Acid: The Mail Component of Olive Oil on Postprandial Metabolic Processes. In Olives and Olive Oil in Health and Disease Prevention, edited by V. R. Preedy and R. R. Watson, pp. 1465-1479. 
DOI:10.1016/B978-0-12-374420-3.00154-6.

Lupoli, R. 2010. L’insecte médicinal. Ancyrosoma, Paris.

Manno, N., W. E. Zelada, C. T. Medina, C. T. Leon, C. Schwarzinger, M. List, W. Schoefberger, F. R. C. Mejía, J. L. Mostacero, A. Battisti, and M. G. Poeletti. 2018. Edible Insects and Other ChitinBearing Foods in Ethnic Peru: Accessibility, Nutritional Acceptance and Food-Security Implications. Journal of Ethnobiology 38:424-447. DOI:10.2993/0278-0771-38.3.424.

Mazars, G., E. Nastari-Micheli, and C. Mazars. 2004. Recherches Ethnopharmacologiques sur les Insects et Autres Arthropodes: L'intérệt de la Pharmacopée Chinoise Traditionnelle. Ethnopharmacologia 34:1322.

MINEDU/Ministerio de Educación. 2013. Documento Nacional de Lenguas Originarias del Perú. MINEDU/ Ministerio de Educación, Lima, Peru.

Onore, G. 2005. Edibles Insects in Ecuador. In Ecological Implications of Minilivestocks, edited by M. G. Paoletti, pp. 343-352. Science Publishers, Enfield, $\mathrm{NH}$.

Paoletti, M. G., E. Buscardo, and D. L. Dufour. 2000. Edible Invertebrates among Amazonian Indians: A Critical Review of Disappearing Knowledge. Environment, Development and Sustainability 2:195-225.

Pinazo-Duran, M. D., and L. Boscá-Gomar. 2012. Propiedades Antiinflamatorias de los Ácidos Grasos Poliinsaturados Omega-3. Indicaciones En Oftalmología. Archivos de la Sociedad Española de Oftalmologia 87:203-205.

DOI:10.1016/j.oftal.2012.04.003.

Sánchez, P., J. V. Hernandez, K. Haffe, and H. Cerda. 1993. Biecología Del Cocotero Rhynchophorus Palmarum L. Boletin de Entomología Venezolana 8:9397.
Sancho, D., M. J. Alvarez, and L. R. Fernández. 2015. Insectos y Alimentación. Larvas de Rhynchophorus Palmarum L, un Alimento de los Pobladores de la Amazonía Ecuatoriana. Entomotropica 30:135-149.

Sancho, D., D. L. Valverde, G. D. Saravia, and G. M. J. Álvarez. 2015. Caracterización del Extracto Graso de Larvas de Rhynchophorus Palmarum L. Ciencia y Tecnología de Alimentos 25:39-43.

Santos, N. M. 2011. Insetos Comestíveis Na Alimentação Humana: Estratégia de Sobrevivência e Segurança Alimentar. In Antroentomofagia: Insetos na Alimentação Humana, edited by E. M. Costa Neto, pp. 123-138. Feira de Santana, UEFS Editora, Brasil.

Valenzuela, B. R., O., G. Tapia, E. M. González, and B. A. Valenzuela. 2011. Ácidos Grasos Omega-3 (EPA Y DHA) y su Aplicación en Diversas Situaciones Clínicas. Revista Chilena de Nutrición 38:356-367.

Vargas, G. E., G. Espinoza, C. Ruiz, and R. Rojas. 2013. Valor Nutricional de la Larva de Rhynchophorus Palmarum L.: Comida Tradicional en la Amazonía Peruana. Revista de la Sociedad Química del Perú 79:6470.

Vera, C., and A. Brand. 2012. Aramanday Guasu (Rhynchophorus Palmarum) Como Alimento Tradicional Entre os Guarani Ñandéva na Aldeia Pirajuí. Tellus 23:97-126.

Waite, M., and S. J. Wakil. 1962. Studies on the Mechanism of Fatty Acid Synthesis XII. Acetyl Coenzyme a Carboxylase. Journal of Biological Chemistry 237:2750-2757. 